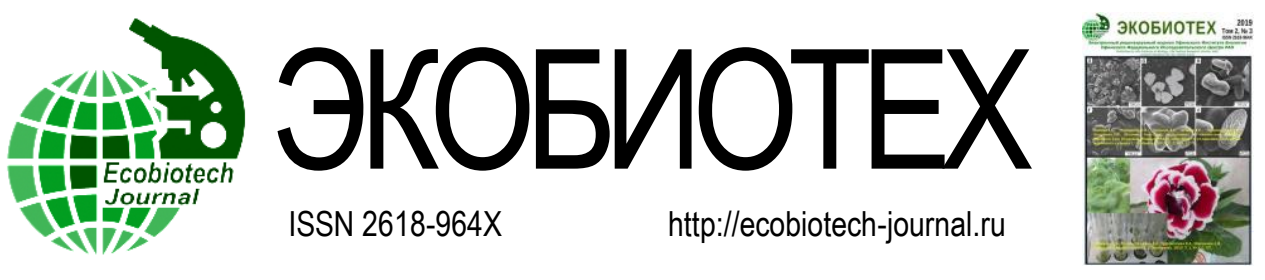

\section{ИСПОЛЬЗОВАНИЕ ИЗОЛЯТОВ ДРОЖЖЕЙ В КАЧЕСТВЕ ИСТОЧНИКА КОРМОВОГО БЕЛКА}

\section{Галяутдинова Е.P.1, Гальперина А.P. ${ }^{2}$}

${ }^{1}$ Волжско-Каспийский филиал Всероссийского научноисследовательского института рыбного хозяйства и океанографии (КаспНИРХ), Астрахань, Росссия E-mail: Ekaterina-grigor@rambler.ru

2 Астраханский государственный технический университет, Астрахань, Росссия

E-mail: alina_r_s@rambler.ru

В работе представлены материалы по определению физиолого-биохимических свойств дрожжей, изолированных из образцов слизи, жабр, печени и кишечника от семи особей сома европейского (Silurus glanis L., 1758). Установлено, что они способны использовать широкий спектр углеводов, чувствительны к основным противогрибковым препаратам. Для наибольшего прироста биомассы дрожжей рекомендуется использование среды, с добавлением дыни и соблюдение температурного режима культивирования $-28{ }^{\circ} \mathrm{C}$.

Ключевые слова: дрожжи, сом европейский, кормовой белок, чувствительность изолятов, противогрибковые препараты

\author{
USE OF YEAST ISOLATES \\ AS A SOURCE OF FOOD PROTEIN \\ Galyautdinova E.R. ${ }^{1}$, Galperina A.R. ${ }^{2}$ \\ 1 Volga-Caspian branch of Russian Federal Research \\ Institute of Fisheries and Oceanography \\ (Caspian Fisheries Research Institute), Astrakhan, Russia \\ E-mail: Ekaterina-grigor@rambler.ru \\ 2 Astrakhan State Technical University, \\ Astrakhan, Russia \\ E-mail: alina_r_s@rambler.ru
}

The paper presents materials for determining the physiological and biochemical properties of yeasts isolated from specimens of mucus, gills, liver and intestines from seven specimens of the European catfish (Silurus glanis L., 1758). It is established that they are able to use a wide range of carbohydrates, sensitive to the main antifungal drugs. For the greatest increase in yeast biomass, it is recommended to use the medium, with the addition of melon and keeping the cultivation temperature mode at $28^{\circ} \mathrm{C}$.

Keywords: yeast, European catfish, feed protein, isolate sensitivity, antifungal drugs

Поступила в редакциию: 11.09.2019

\title{
DOI: 10.31163/2618-964X-2019-2-4-525-528
}

\section{ВВЕДЕНИЕ}

Со второй половины X X в. дрожжи начали активно применять в качестве кормовой добавки в животноводстве, повышая при этом ценность кормов, прежде всего за счет содержащихся в них метаболитов [Храпова, 2011]. Дрожжевую клетку можно рассматривать как кладезь различных компонентов, таких как протеины, витамины, нуклеотиды, аминокислоты и микроэлементы. Продуцируемые ими метаболиты обладают повышенной лабильностью, которая обуславливает высокую эффективность их ферментативной системы. Эта особенность позволяет им выживать при значительных колебаниях температуры, влажности, состава и свойств субстрата [Ралкова, 2016]. В природе дрожжи населяют преимущественно богатые сахарами субстраты, утилизируя углеводы питательной среды, подвергая их ферментативному расщеплению [Магомедова, 2013]. Сырьем для наращивания дрожжевой биомассы в производстве могут служить как углеводороды нефти, так и гидролизаты различных сельскохозяйственных отходов. При этом растительная масса является наиболее перспективным сырьем для получения кормового белка микробного происхождения [Ралкова, 2016]. Поиск биологически активных соединений, синтезируемых дрожжами, и подбор сред для наибольшего накопления биомассы в настоящее время остается весьма актуальным направлением современной биотехнологии. В связи с чем, 
целью работы являлось изучение физиолого-биохимических свойств природных дрожжевых изолятов, входящих в состав микробиоты сома европейского (Silurus glanis L., 1758) и определение наиболее перспективного изолята, как потенциального источника кормового белка.

\section{МАТЕРИАЛЫ И МЕТОДЫ ИССЛЕДОВАНИЯ}

Объектом исследования являлись дрожжевые культуры, изолированные из образцов слизи, жабр, печени и кишечника от семи особей сома европейского (Silurus glanis L., 1758).

Для выделения изолятов чистых дрожжевых культур и изучения их физиологобиохимических свойств использовали серию последовательных пересевов на питательную среду - Сабуро [Бабьева, 1979]. Выделенные изоляты дрожжей тестировали на способность к росту при температуре, находящейся в пределах оптимальной $-28{ }^{\circ} \mathrm{C}$ (контроль), и сверхоптимальной - 37 и $60{ }^{\circ} \mathrm{C}$ (опыт). В работе использовали двухсуточные культуры, которые рассеивали на селективную среду Сабуро и инкубировали при указанных температурных режимах [Меледина, 2013].

Для изучения способности к утилизации сахаров (глюкозы, лактозы, сахарозы, арабинозы, мальтозы, фруктозы, маннозы, тригалоза, ксилозы, галактозы) производили посев дрожжевых изолятов на дифференциально-диагностические тесты с использованием растворов специфических субстратов на основе фосфатных буферов. Инкубирование производили в течение 24 ч при температуре $28^{\circ} \mathrm{C}$. Учет результатов оценивали визуально [Меледина, 2013].

Для изучения влияния противогрибковых препаратов на выделенные дрожжевые изоляты использовали следующие препараты: флуконазаол, клотримазол, тербинафин, нистатин, пимафуцин, при концентрациях 10, 20и 30 мг/мл. Определение активности антимикотиков проводили методом лунок. Контролем служил физиологический раствор без противогрибковых препаратов. Через 24-48 ч. термостатирования при $28{ }^{\circ} \mathrm{C}$ измеряли диаметр зон задержки роста и проводили учет результатов. Отсутствие роста штриха дрожжевого изолята указывало на угнетение его антимикотическим веществом. Если же штрих развивался в непосредственной близости от лунки, это означало, что данный изолят устойчив к действию антимикотика[Нетрусов, 2005].Для проведения регрессионного анализа использовали программу Microsoft Excel.

При подборе естественных сред для исследуемого изолята дрожжей использовали плотные среды, основой которых являлись растительные субстраты (дыня, арбуз, тыква и томаты). Инкубирование производили в течение 3-4 суток. Продуктивность культуры оценивали по накоплению дрожжевой биомассы. Контролем являлся посев на среде Сабуро. При подборе компонентов питательной среды руководствовались прописями питательных сред для культивирования дрожжей [Бабьева, 2004; Нетрусов, 2005].

\section{РЕЗУЛЬТАТЫ И ОБСУЖДЕНИЕ}

В результате ряда последовательных пересевов на агаризованную среду Сабуро выделено 16 дрожжевых изолятов, отличающихся по культуральным и морфологическим признакам.При оценке температурных приоритетов выявлено, что высокий темп роста биомассы дрожжевых клеток при температуре $28{ }^{\circ} \mathrm{C}$ наблюдали в первые 24 ч у всех изолятов, однако с повышением температуры скорость прироста биомассы снижалась, при этом на три изолята, выделенных из печени и жабр, повышение температуры до $37{ }^{\circ} \mathrm{C}$ 
оказывало влияние лимитирующего характера. При температуре $60^{\circ} \mathrm{C}$ отмечали слабый рост биомассы только у единичных культур. Более устойчивыми в отношении температурных параметров были дрожжи, населяющие жабры и слизь, что, скорее всего, связано с высокой адаптивной способностью последних, обусловленной тесным контактом их биотопов с окружающей средой, где перепады температур более значительные.

Оценка возможности утилизации сахаров дрожжами показала, что они способны использовать широкий спектр углеводов. Все выделенные изоляты дрожжей использовали маннозу и галактозу в качестве источников питания. Несколько реже дрожжи потребляли арабинозу (93,75 \% изолятов), глюкозу (87,5 \%) и мальтозу (75 \%) что закономерно, поскольку все вышеуказанные моносахариды относятся к наиболее доступным для микроорганизмов источникам углеводов. Значительно меньшее количество изолятов обладало способностью к утилизации, таких сахаров как сахароза (37,5 \% изолятов), фруктоза $(18,75 \%)$, ксилоза $(12,5 \%)$, лактоза $(6,25 \%)$ и тригалоза $(6,25 \%)$, поскольку большинство из них относится к более сложным соединениям, расщепление которых энергозатратно и требует дополнительных условий культивирования. Ведутся дальнейшие исследования по использованию спектра углеводов выделенными дрожжами в связи с перспективностью использования их для переработки вторичных ресурсов пищевой и сельскохозяйственной промышленности для получения кормового белка.

При изучении влияния противогрибковых препаратов на дрожжи установлено, что на большинство выделенных культур препараты оказывали микоцидное действие. Следует отметить, что наиболее активной фармакологической группой в отношении дрожжей являлись противогрибковые препараты группы макролидов (пимафуцин) и полиеновых препаратов (нистатин), которые угнетали рост дрожжей в 100 \% случаев при минимальной подавляющей концентрации 10 мг/л. При воздействии препарата группы аллиламинов(тербинафин) регистрировали ярко-выраженную корреляционную зависимость количества чувствительных изолятов от величины концентрации действующего вещества (r0,9969). К препаратам имидазольного ряда (клотримазол) и группы азолов (флуконазол) дрожжи были устойчивы в большинстве случаев (r - 0,9306).

При оценке размера клеток выделенных дрожжей, как одного из факторов, влияющих на скорость прироста биомассы, выявлено, что наибольшейвеличиной обладал изолят, выделенный из образцов слизи и предположительно относящийся к роду Rhodotorula. При подборе среды для наибольшего прироста биомассы установлено, что все испытуемые растительные субстраты (арбуз, дыня, тыква, томаты) благоприятны для роста дрожжей. Наиболее перспективной растительной средой для максимального прироста биомассы является среда, основой которой является дыня (табл. 1).

Таблица 1. Влияние состава среды на рост культуры дрожжей

\begin{tabular}{|l|c|c|}
\hline $\begin{array}{l}\text { Среда с добавлением } \\
\text { растительного субстрата }\end{array}$ & Размер клеток, мкм & $\begin{array}{c}\text { Выходная величина } \\
\text { (у- прирост биомассы), мг/л }\end{array}$ \\
\hline Арбуз & $2,8-1,5 ; 1,5-1,1$ & 0,218 \\
\hline Дыня & $2,8-1,5 ; 1,6-1,2$ & 1,713 \\
\hline Тыква & $2,8-1,5 ; 1,4-1,3$ & 0,198 \\
\hline Томаты & $1,7-1,2 ; 1,4-1,1$ & 0,275 \\
\hline
\end{tabular}

Таким образом, при изучении влияния температуры на природные дрожжевые изоляты установлено смещение температурных границ выживания в более высокую область 
для изолятов, биотопы которых находились в тесном контакте с окружающей средой. Отмечена способность дрожжевых культур к использованию широкого спектра углеводов, что представляет большой практический интерес в биотехнологии. Установлено, что большинство выделенных культур оказались чувствительными к основным противогрибковым препаратам. Наиболее чувствительными выделенные дрожжи были к антимикотикам группы макролидов (пимафуцин) и полиеновых препаратов (нистатин). При изучении влияния состава среды на рост культуры дрожжей выявлено, что все растительные субстраты (дыня, арбуз, тыква, томаты) благоприятны для роста наиболее перспективного изолята. Для получения максимального прироста биомассы дрожжей рекомендуется использование растительной среды, основой которой является дыня, в связи, с чем необходимы дальнейшие исследования о возможности применения выделенных дрожжей для переработки вторичных ресурсов, содержащих повышенное количество сахаров пищевой и сельскохозяйственной промышленности для получения кормового белка.

\section{СПИСОК ЛИТЕРАТУРЫ}

1. Бабьева И.П., Чернов И.Ю. Биология дрожжей. - М.: Тов. науч. НМК, 2004. - 239 с.

2. Бабьева И.П., Голубев В.И. Методы выделения и идентификации дрожжей. -М.: Пищевая промышленность, 1979. -120 с.

3. Магомедова Е.С. Влияние сверхоптимальных температур на свойства природных дрожжей S.Cerevisiae / Е.C. Магомедова, Д.А. Абдуллабекова // Вестник Дагестанского научного центра РАН. - Махачкала, 2013. - с. 38-41.

4. Меледина Т.В., Давыденко С.Г., Васильева Л.М. Физиологическое состояние дрожжей: Учеб. пособие. - СПб.: НИУ ИТМО; ИХиБТ, 2013. - 48 с.

5. Нетрусов А. И. Практикум по микробиологии. М: Академия, 2005. 608 с.

6. Ралкова В.С. Возможность использования изолятов дрожжей, выделенных из биологических объектов, для утилизации углеводов, увеличения биомассы-источника кормового белка / В.С. Ралкова, О.А. Артемьева, Е.Н. Колодина, Д. А. Никанова // Актуальные проблемы гуманитарных и естественных наук. - Москва, 2016. - с. 66-70.

7. Храпова А.В. Скрининг новых штаммов дрожжей для получения кормового белка / А.В. Храпова, О.Б. Сопрунова // Известия Самарского научного центра Российской академии наук. - 2011. - Т. 13, №5(3). - С. 210-213. 